Review article

\title{
Physical disabilities in nursing - the use of selected tools to monitor physically disabled patients' needs
}

\author{
Jan Neugebauer*, Valérie Tóthová \\ University of South Bohemia in České Budějovice, Faculty of Health and Social Sciences, České Budějovice, Czech Republic
}

\begin{abstract}
Introduction: The multidisciplinary concept of physical disability (in comparison with other disabilities, such as mental or social) is considered less problematic. In nursing, we can point out many variables (incontinence, a higher risk of decubitus ulcers, spasticity, etc.) whose combination can be called physical disability.

Goal: The goal of this study is to map selected evaluation and measuring tools that can be applied in the assessment of physically disabled patients' needs.

Methods: This review study was carried out to map selected evaluating tools for the assessment of physically disabled patients' needs. The data were gained from academic databases of Scopus, Web of Science, Wiley Online Library, Science Direct, Ebsco and Pubmed between 2015 and 2019. After the classification by the established criteria, we identified 12 relevant sources.

Results: We found 5 possibly relevant tools for the assessment of physically disabled patients' needs. The specific tools were WHODAS 2.0, MDS, MDS-BV, SDS and ICF.

Conclusions: All identified tools can be used for the assessment of physically disabled patients and are suitable for implementation in clinical practice. It was necessary to carry out this study in the Czech clinical practice to learn the effectiveness, usefulness, validity, reliability, specifics and sensitivity of selected tools.
\end{abstract}

Keywords: Model Disability Sheehan Disability Scale; Model Disability Survey - Brief version; Nursing; Survey; The International Classification of Functioning, Disability and Health; Physical disability; WHODAS 2.0

\section{Introduction}

In general, physical disability is a familiar concept. Although it is more a social issue, it is closely related to nursing. If we focus on the assessment of the concept of physical disability, it is necessary to define it correctly. This issue can be perceived from different points of view. From the sociological point of view, we can say that it is a physical deficit that prevents the performance of daily activities (Čírtková et al., 2007). From the psychological point of view, they are visible changes that are reflected in personality (Opatřilová and Zámečníková, 2007). From the medical point of view, they are the defects of the locomotive system including the vascular and nervous system (Kočová et al., 2017) that can lead to organic changes (Kučírek, 2017). The WHO defines disability as the interaction between two people including contextual factors (personal and environmental) (Leonardi et al., 2006). The general nursing point of view connects individual opinions and defines physical disability as any pathological change in the locomotive system that leads to the limitations of the physiological function of bones, joints, muscles, tendons and finally life- style (Hanková and Vávrová, 2016). To understand the issue of physical disability in the field of nursing and synthesize the total view, a rehabilitation branch was created. According to Lutz and Bowers (2003), the branch was considered the most contributive in nursing physically disabled patients. The definition of physical disability was modified in this branch. Its primary goal is to minimize a disability by understanding the functional perspective of a patient. Nursing care tries to perfect the life of the disabled, i.e. without assistance (Lutz and Bowers, 2003).

Disabilities in nursing are seen in history, e.g. conceptual models that pointed out human individuality and a spectre of needs (Henderson, 1978), specifically modified nursing care and interventions (Bond and Bond, 1982). The connection between nursing and disabilities in clinical practice can be seen especially in medical, social or combined facilities (Nagaratnam and Nagaratnam, 2019). The Czech Statistical Office reacted to the increasing disabled numbers in 2007 and co-operated with the Institute of Health Information and Statistics of the Czech Republic in one of the first studies of disabled people (Kalnická and Votinský, 2008). Based on the results of their study, there was a continuous demand for educational

\footnotetext{
* Author for correspondence: Jan Neugebauer, University of South Bohemia in České Budejjovice, Faculty of Health and Social Sciences, U Výstaviště 26, 37011 České Budějovice, Czech Republic; e-mail: Neugebauer@zsf.jcu.cz http://doi.org/10.32725/kont.2019.032

Submitted: 2019-03-28 • Accepted: 2019-08-11 • Prepublished online: 2019-09-26 
materials that would adequately prepare medical professionals and maintain the concept of the continuously increasing level of nursing care, bio-psycho-social-spiritual interpretation and holism.

In the Czech nursing practice, many evaluating tools are used, which are designed especially for general use - assessing the risk of fall, decubitus ulcers etc. Considering the fact that there is neuropathy in patients with physical impairments, it is necessary that some screenings are carried out more frequently. It ensures better effectiveness and quality of care and reduces undesirable accidents and complications during hospitalization. This information is dealt with by the Washington Group (WG) on Disability Statistics, which includes 135 registered members from world countries. Their intention is testing the effectiveness of measuring and evaluating tools (Madans et al., 2011). The WG co-operates with other organizations that join clients with physical impairments in world countries. Together, they co-operated in the development of the basic and extended model (Short Set of Six Disability Question/Extended Question Set on Functioning) which contains 15/37 questions regarding sight, hearing, cognitive abilities, mobility, fear or depression, pain, communication, fatigue and upper bodily functions (Palmer and Harley, 2012). Contemporarily, the WG co-operates with the WHO. In 2001, these organizations reacted to the growing demand on the International Classification of Functioning, Disability and Health (ICF): in 2013, the WHO with the Disability Assessment Schedule 2.0 II (WHODAS 2.0 II) and the Model Disability Survey (MDS) in 2017 (Gold, 2014; WHO, 2001, 2017). The mentioned evaluating tools are used globally. The ICF and WHODAS 2.0 II were translated into Czech. Their implementation in nursing was uploaded on the web pages of the Institute of Health Information and Statistics of the Czech Republic including the manual and it is currently in the phase of online testing and searching for errors.

Sheehan et al. (2011) consider the assessment of patients necessary for modern nursing because we cannot monitor the improvements or worsening of health conditions, establish interventions or update care plans. To understand a physical impairment, it is necessary to be empathic and patient because patients themselves must accept their impairments and a new lifestyle. For this reason, it is necessary for nurses to be sufficiently educated regarding this issue, communicate with patients and support and motivate them. All reflected needs of patients are subjective and, although they may seem trivial, they can be crucial for patients. Subjective assessments of current situations regarding patients' health conditions were dealt with in the context of mental disorders. To understand a patient's condition, their way of thinking, connections, creativity and the view of their life, the Sheehan Disability Scale (SDS) evaluation tool was created. Its goal is the assessment of the impairments regarding work, social status and family (Coles et al., 2014). The original version was focused especially on mental health and the days of the monitorings were filed, after which the patients were excluded from daily life (Leon et al., 1997). This evaluation tool is unique for its general use and the assessments are subjectively influenced by the statements of monitored patients (Sheehan et al., 2011). The most modern is the modified version of the evaluation tool from 2008, which was aimed at patients with bipolar affected disorder (Arbuckle et al., 2009). When this tool is included in clinical practice, we can record patients' views on their current condition and their understanding of reality. The assessment of the mentioned 3 areas reflects what needs are satisfied and which are not. When individual components are included in the nursing plan, a nurse can gain complex information on patients' health condition, level of independence, physical functions, risk areas and patients' subjective view of themselves.

\section{Goal}

The goal of this article is to map evaluation and measuring tools that can be applied in the assessment of the needs of patients with impairments.

\section{Materials and methods}

In this review study, we used the method of Tranfield et al. (2003), who formulated the clinical issue by the acronym CIMO (Context, Interventions, Methods, Outcome). The main goal was to find out what evaluating tools $(C)$ used in patients with impairments $(\mathrm{M})$ were convenient for nursing (I) and led to the improvement of care $(\mathrm{O})$.

After completing the clinical issue using the acronym, we selected the keywords that were directly related to the issue. To correctly formulate keywords, we used the experience of Colicchio and Strozzi (2012), who recommend identifying 20 keywords and reducing and formulating them in their final form. The search was carried out between 01/2015 and 01/2019 using the following keywords: Physical disability, evaluating tools, measuring tools, needs, nursing, quality of provided care. The data were extracted from Scopus, Wiley Online Library, Science Direct, Ebsco, PubMed and Web of Science

Another step was the classification of the found publications according to the publication of Newbert (2007). The selection criteria were:

a) the language of publications had to be English or Czech;

b) the time period of publications had to respond to the one set by the researcher;

c) at least one keyword had to be included in the title or keywords of publications;

d) the publications had to be sufficiently valid and related to the topic - we checked it by reading abstracts.

For the verification of validity, we used the instructions of Collins and Fauser (2005) to search especially for quantitative studies, which are better for the verification of validity and reliability of individual tools.

We found a total of 284 publications. Scopus contained 68 sources, Willey Online Library contained 54, Science Direct contained 41, Ebsco contained 27, PubMed contained 75 and Web of Science contained 19 sources. Based on duplicity, we excluded 89 sources. Based on the abstract analysis, we excluded 134 sources. We used 61 full-text sources for document analysis. The final selection left us with 8 sources.

The identification of sources, their selection and inclusion in this study were inspired by the methodology of Gülpinar and Güçlü (2014) and the total process was graphically presented in the PRISMA flow diagram (Diagram 1). We also carried out the content analysis (Table 1) of selected tools, which Green et al. (2006) consider very contributive. It was constructed using the analysis of the mentioned authors and the primary sources of ICF, WHODAS 2.0 II, MDS, MDS-BV, which are available on the web pages of the WHO, and the SDS tool (Sheehan, 1986).

There were a low number of expert studies so we agreed to expand the period and included 4 older studies that specify the individual tools. They are publications that are either primary sources or contain citations from primary sources.

In total, we included 12 relevant publications (Table 2). 


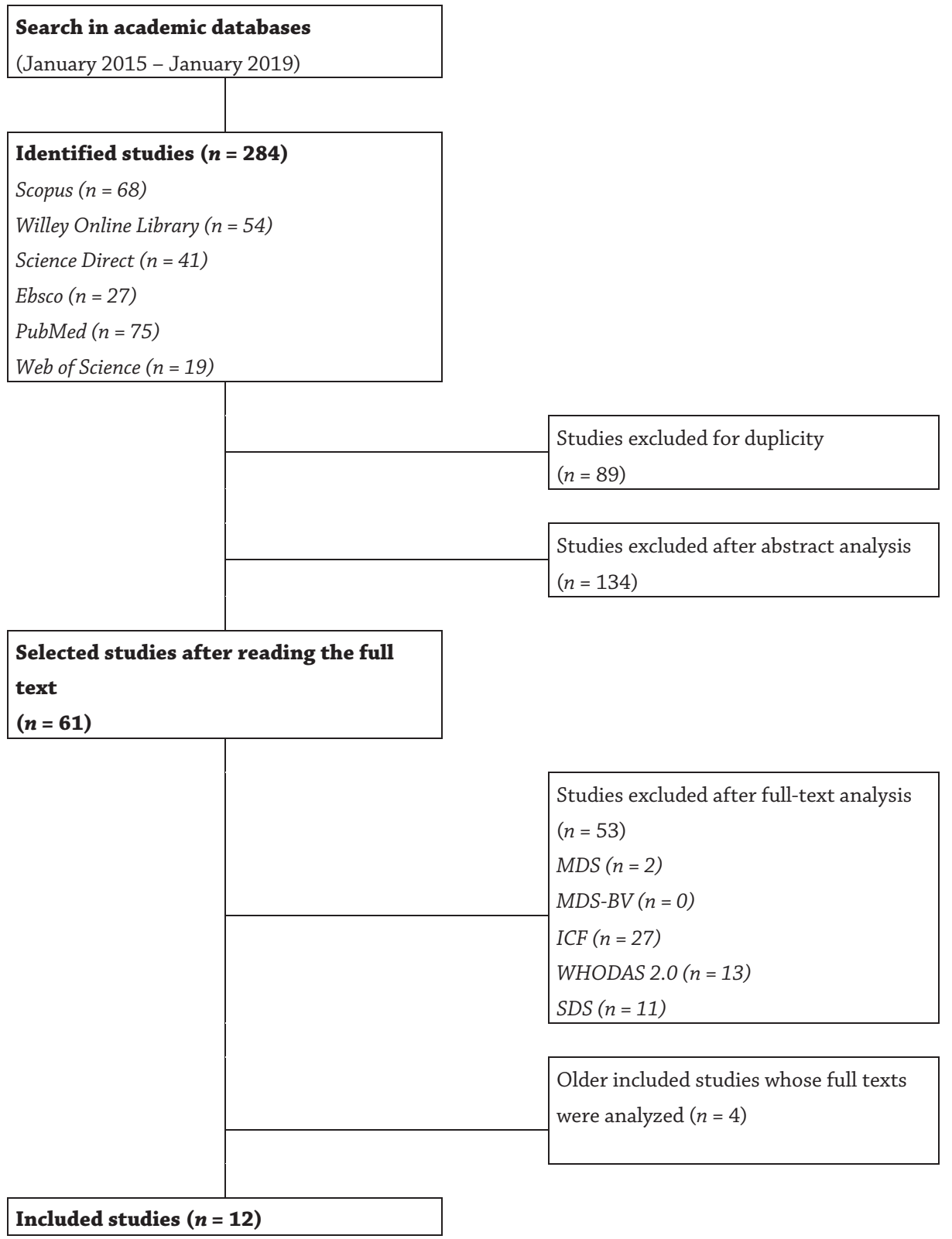

Diagram 1. Prisma flow diagram

\section{Table 1. Identified tools for disorder assessment (Sheehan, 1986; WHO, 2019)}

\begin{tabular}{|c|c|c|c|c|}
\hline Tool & Author (year) & Goal & Primary focus & Assessed areas \\
\hline WHODAS 2.0 II & WHO (2013) & $\begin{array}{l}\text { Disorder } \\
\text { assessment }\end{array}$ & Community nursing & $\begin{array}{c}\text { Cognitive functions; Mobility; Independence; Interaction; } \\
\text { Activities; Participation }\end{array}$ \\
\hline MDS & WHO (2017) & $\begin{array}{l}\text { Disorder } \\
\text { assessment }\end{array}$ & $\begin{array}{l}\text { Social care } \\
\text { Constitutional care } \\
\text { Research }\end{array}$ & $\begin{array}{l}\text { Demography; Work and studies; Environment; Functions; } \\
\text { Health condition; Personal assistance, aids and facilitation; } \\
\text { Use of medical care; Physical and mental well-being; } \\
\text { Encouragement }\end{array}$ \\
\hline MDS-BV & WHO (2017) & $\begin{array}{c}\text { Disorder } \\
\text { assessment }\end{array}$ & $\begin{array}{c}\text { Social care } \\
\text { Constitutional care }\end{array}$ & $\begin{array}{l}\text { Environmental factors; Functions; Physical condition; } \\
\text { Personal assistance and helping aids }\end{array}$ \\
\hline ICF & WHO (2001) & $\begin{array}{c}\text { Disorder } \\
\text { assessment }\end{array}$ & $\begin{array}{c}\text { Social care } \\
\text { Constitutional institution } \\
\text { Nursing }\end{array}$ & $\begin{array}{l}\text { Functions and impairments; Activity and participation; } \\
\text { Contextual factors }\end{array}$ \\
\hline SDS & $\begin{array}{l}\text { Sheehan } \\
\text { (1986) }\end{array}$ & $\begin{array}{l}\text { Assessment of } \\
\text { psychological } \\
\text { condition }\end{array}$ & Psychiatry & Work/school; Social life; Family and relationships \\
\hline
\end{tabular}


Table 2. Overview of used studies

\begin{tabular}{|c|c|c|c|c|}
\hline $\begin{array}{l}\text { Author } \\
\text { (publishing year) }\end{array}$ & Studied tool & Sample group & Research type & Goal \\
\hline $\begin{array}{l}\text { Sabariego et al. } \\
\text { (2015) }\end{array}$ & MDS & $\begin{array}{l}500 \text { adults who were } \\
\text { labelled as "the head of the } \\
\text { household" }\end{array}$ & Quantitative & $\begin{array}{l}\text { To find whether it is possible to use the MDS } \\
\text { tool to determine the level of impairment and } \\
\text { recommend it for global use. }\end{array}$ \\
\hline Li et al. (2016) & ICF & $\begin{array}{l}40 \text { patients who underwent } \\
\text { transverse lesion of spinal } \\
\text { cord }\end{array}$ & Quantitative & $\begin{array}{l}\text { To find the use of the ICF tool for nursing } \\
\text { practice regarding patients who underwent } \\
\text { transverse lesion of the spinal cord. }\end{array}$ \\
\hline Lisowska (2017) & MDS and MDS-BV & - & Comparative study & $\begin{array}{l}\text { To theoretically analyze the MDS and MDS-BV } \\
\text { tools in comparison to the WG requirements } \\
\text { and their models (SV-WG, EV-WG). }\end{array}$ \\
\hline Üstün et al. (2010) & WHODAS 2.0 & $\begin{array}{l}>65,000 \text { of the global } \\
\text { population }\end{array}$ & Quantitative & $\begin{array}{l}\text { To find the use and usefulness of the } \\
\text { WHODAS } 2.0 \text { tool. }\end{array}$ \\
\hline $\begin{array}{l}\text { Carlozzi et al. } \\
\text { (2015) }\end{array}$ & WHODAS 2.0 & $\begin{array}{l}477 \text { patients with HD } \\
\text { who were divided into } 2 \\
\text { categories }\end{array}$ & Quantitative & $\begin{array}{l}\text { Testing the validity and reliability of the } \\
\text { WHODAS } 2.0 \text { tool in patients with HD. }\end{array}$ \\
\hline Tatli et al. (2019) & ICF-CS & $\begin{array}{c}120 \text { patients who } \\
\text { underwent transverse } \\
\text { lesion of the spinal cord } \\
\text { and who have a physical } \\
\text { disorder }\end{array}$ & Quantitative & $\begin{array}{l}\text { Testing the validity of the ICF-CS tool in } \\
\text { patients who underwent transverse lesion of } \\
\text { the spinal cord and verifying the effectiveness } \\
\text { in clinical practice. }\end{array}$ \\
\hline $\begin{array}{l}\text { Alonso-Prieto et al. } \\
\text { (2019) }\end{array}$ & SDS & $\begin{array}{l}120 \text { patients with traumatic } \\
\text { damage of the spinal cord }\end{array}$ & Quantitative & $\begin{array}{l}\text { Testing the use of the SDS tool for the } \\
\text { assessment of the quality of life of patients } \\
\text { with traumatic damage of the spinal cord. }\end{array}$ \\
\hline Hodgins (2013) & SDS & $\begin{array}{l}21 \text { patients in pre-study } \\
\text { and } 169 \text { in the main study } \\
\text { with addiction - gambling }\end{array}$ & Quantitative & $\begin{array}{l}\text { Testing the use of the SDS tool in patients who } \\
\text { are addicted to gambling and verifying the } \\
\text { effectiveness in clinical practice. }\end{array}$ \\
\hline Lu et al. (2018) & WHODAS 2.0 & $\begin{array}{l}\text { 31,793 schizophrenic } \\
\text { patients }\end{array}$ & Quantitative & $\begin{array}{l}\text { Testing the validity of the WHODAS } 2.0 \\
\text { tool for the area of work disadvantage of } \\
\text { schizophrenic patients. }\end{array}$ \\
\hline Sheehan (1986) & SDS & - & Theoretical publication & $\begin{array}{l}\text { The description of the SDS tool and its } \\
\text { practical application. }\end{array}$ \\
\hline WHO (2017) & MDS, MDS-BV & - & Theoretical publication & $\begin{array}{l}\text { The description of the MDS and MDS-BV and } \\
\text { their practical application. }\end{array}$ \\
\hline WHO (2001) & ICF & - & Theoretical publication & $\begin{array}{l}\text { The description of the ICF tool and its practical } \\
\text { application. }\end{array}$ \\
\hline
\end{tabular}

\section{Results and discussion}

The assessment of the needs of patients with physical disorders is still underestimated in the Czech Republic. Global organizations create preventative programmes, education materials and evaluating tools so that clinical practice is continuously modernized. Part of the evidence of the necessity to have an individual approach to patients with physical disorders was the creation of the WG. Loeb (2016) considers the 37-point evaluating system of disorders as efficient and not time-consuming for clinical practice. Their research, which points out the correct determination of all areas, is confirmed by Madans et al. (2011) as well. They see the expanded evaluating model for disorders as basic, and recommend implementing it in all institutions with impaired patients. These theoretical and empirically verified data are the basic construction tool for the authors of individual tools, which are later analyzed in detail.

Table 1 shows the analysis of evaluating tools that deal with monitoring the needs of patients with a physical disorder. Individual tools are divided by authors and publishing years, their goals, primary areas which it was designed for, and assessed areas.
Table 2 shows the characteristics of individual publications that are used for the description and verification of the validity of selected tools. The Table contains a few categories - the author and publishing year, the tool that is dealt with in the publication, sample group, research type and goals of individual studies.

\section{WHO Disability Assessment Schedule 2.0 (WHODAS 2.0)}

This tool is considered one of the most modern and effective ways of assessing impairments/disadvantages (Konecky et al., 2014). Silveira et al. (2018) point out the possibility of using it not only in clinical practice but in research as well. Researchers and experts can choose from 3 versions (12, 24 and 36 questions). The 36 -question version was translated into $\mathrm{Czech}$ and is available on the web pages of IHIS CR 29. 8. 2018 (IHIS $C R, 2018)$. Its validity was confirmed by translations into a few world languages including Portuguese (Silva et al., 2013), Spanish (Almazán-Isla et al., 2014) or Chinese (Chiu et al., 2014). The application of the WHODAS 2.0 tool is directed at psychiatric institutions and used in combination with ICF in modern clinical practice. Lu et al. (2018), who studied the use of the WHODAS 2.0 tool in schizophrenic patients in Thailand, 
were focused on determining disadvantages in work area and confirmed that it was possible to apply the WHODAS 2.0 tool regarding all types of disadvantage/impairment.

Üstün et al. (2010) were focused on verifying the effectiveness of the WHODAS 2.0 tool in clinical practice. The analysis of the WHODAS 2.0 tool showed it to be very effective, especially for its structural division of individual areas (understanding and communication; self-care; mobility; interpersonal relationships; work and the role in the household; community and social role) and evaluation on the point scale 0-4 where the minimum score was 0 (the highest health condition level) and the maximum was 48 (low health condition level). From the administrative point of view, the tool can be used independently with partial help from a carer or full help and led as an interview. The total time spent on using the tool is estimated to be less than 5 minutes.

Carlozzi et al. (2015) studied the use of the WHODAS 2.0 tool (12 questions) as the indicator of the quality of life of patients with Huntington disease and compared it to the generally used tools, such as Health-Related Quality of Life (HRQOL), RAND - 12 Health Status Inventory (HSI), EQ-5D and the Total Functional Capacity scale (TFC). The sample group included 475 patients with prodromal $(n=190)$ or manifested $(n=$ 285) Huntington disease. All tools are filed as contributive for clinical practice from the point of view of the assessment of the quality of life but the authors consider the WHODAS 2.0 tool the most contributive. This tool is structurally configured to reflect all necessary areas to objectively assess the quality of life in accord with the analysis of needs by the WHO and WG. The authors confirm that, when compared to other tools (including the 32-question WHODAS 2.0), the 12-question WHODAS 2.0 is the most convenient. They recommend implementing it in clinical practice and encourage the realization of other studies that focus on specific illnesses that lead to disadvantages/impairments.

\section{Model Disability Survey (MDS) a Model Disability Survey - Brief version (MDS-BV)}

The MDS is considered the most modern evaluating tool that is used to map disadvantages/impairments in the world. The WHO developers focused especially on individual barriers and problems associated with disadvantages/impairments. Whenever research involves a questionnaire, the tool is constructed to be filled in during an interview, which leaves a researcher with the choice to give a patient the possibility to give a subjective assessment. The MDS tool is limited because it has no open questions and patients have no possibility to express their emotions and subjectively assess their condition. It is also limited by the exhaustive mode that prevents it from being used in clinical practice (WHO, 2017).

MDS-BV is the subsidiary tool of the MDS designed for practical purposes and the implementation in clinical practice (WHO, 2017). The content of the MDS-BV responds to the expanded model designed by the Washington Group on Disability Statistics (WG).

Sabariego et al. (2015) point out the pilot testing of the MDS in Cambodia. In their pre-study, the authors researched the validity, reliability and practical use for the reflection of the level of disadvantage/impairment in the given area. The variety of the results is inclined toward the use of the MDS tool for research more than clinical practice. The main reason is its exhaustive character - time length (approximately $120 \mathrm{~min}$.) and the number of questions (more than 300). The authors recommend this tool for the monitoring of the level and type of disadvantage/impairment in individual areas or the use in individual institutions but only monthly or annually or during the admission for long-term hospitalization.

The WHO reacted to the results of this research and developed a shorter version of the MDS-BV, which assesses only categories that are crucial for understanding human individuality.

Lisowska (2017), who dealt with measuring the level of disadvantages/impairments, assesses the MDS-BV as currently the most contributive for clinical practice and daily assessments. She compared this evaluating tool to the expanded version by the WG. Her work resulted in recommending the clinical practice and daily or weekly assessments of patients using the MDS-BV rather than the expanded version by the WG. Both tools provide the same information on the patients' current condition. However, the MDS-BV is better arranged into 4 assessed areas and takes less time. The author recommends starting studies that would confirm her theoretical basis in the nursing, social and community sphere.

Considering the date of the publishing of both tools, no relevant sources that would empirically confirm the theory have been published so far. The testing of the original version of the MDS is supported by the WHO in many countries that carried out population studies before their own researches. The MDS-BV is good for routine testing or clinical practice and contemporarily tested in many countries. There has been no evidence of validity, mistakes or problems.

\section{The International Classification of Functioning, Disability and Health (ICF)}

The publishing of the ICF in 2001 was motivated by WG, which co-operated with the WHO in developing the categories for effective assessments of disadvantages/impairments (WHO, 2001). The question that remains is which problems to eliminate, what other factors are necessary to be assessed and how to implement individual criteria in the nursing process. According to Castaneda et al. (2014), the subcategories of the ICF provide nursing staff with relevant data and enable them to proceed by theoretically described and clinically verified steps. The use of the ICF is directed towards rehabilitation, especially if patients have a physical disorder (Ehrmann et al., 2018). The ICF was tested by the standard Health-Related Quality of Life (HRQOL) tool and the results showed the difference in the effectiveness of the assessment of needs using the ICF (Cieza and Stucki, 2005). Due to the effectiveness and practicality of the tool, the domains are continuously expanded, e.g. regarding the paediatric patient (Sanches-Ferreira et al., 2018; Simeonsson et al., 2009). The ICF is also very contributive because of the interconnection of the individual components, such as impairment, environment, used aids and the work with human individuality (Bradley et al., 2009). The disadvantage of the ICF is the period when it was created because it can seem outdated due to the continuously expanding spectre of requirements.

Li et al. (2016) focused on patients with physical impairments, specifically after a transverse spinal cord lesion. Patients $(n=40)$ were nursed during their hospitalization and 3 days after discharge using the guidelines from the ICF categories. The authors say that the tool is very convenient because it focuses on all areas that should not be omitted in nursing, such as bodily functions, body structure, activity, components, environmental factors, etc. The authors recommend implementing the ICF in nursing practice and point out the suitableness of its use in Orthopaedics, spinal units, Traumatology and other post-injury departments. 
Tatli et al. (2019) were focused on the use of the ICF (specifically The International Classification of Functioning - Core Set (ICF-CS) regarding patients who underwent a transverse spinal cord lesion and with physical disorders. Assessing their disorders and accepting the ICF strategy, the authors point out the multidisciplinary conception of this issue, which should assess disorders as well as the total health condition caused by disorders (muscle atrophy and asthenia, respiratory and cardiovascular problems, the increased risk of decubitus, problems with evacuation and sexual dysfunction, spasticity, depressions, pain, the increased risk of fractures etc.). All of these aspects should be assessed (according to the level of the impairment) before starting a rehabilitation programme. The research included 120 patients, who were continuously monitored and treated for two years using the ICF-CS tool. The results point out problems in 55 areas of the ICF (63 were assessed). The authors point out the high level of validity and reliability of the ICF tool regarding the assessment of specific illnesses that lead to a physical impairment. They recommend implementing the ICF-CS model in nursing practice, which would ensure the complex, effective and high-quality care with the EBN application and unified methods of nursing practice.

Due to these findings that are based on researches, we have come up with the question of whether the ICF is a suitable tool for the assessment of the needs of patients with physical disorders in the Czech Republic or not. Modern researches point out the suitability of the tool However, if we want a more modern and equally effective tool, we will find the WHODAS 2.0.

\section{Sheehan Disability Scale (SDS)}

The original version of the Sheehan Disability Scale was published in 1983. Its goal was the assessment of impairments regarding mental health and the subjective view of patients on their own impairment regarding work, social and family status (Sheehan, 1986). If the results were continuously recorded, patients would provide nursing staff a sufficient assessment of their own contemporary status, mood and problems that are necessary to be solved. In case of the insufficient competence of the staff to take necessary steps, the assessments can help other experts, such as psychologists and other therapists. The application of the SDS in modern nursing is possible if the original scale is used. According to Arbuckle et al. (2009), the modifications are not sufficiently relevant for these purposes. The validity and reliability of the tool have been tested several times and the SDS has been translated into more than 40 world languages (Sheehan and Sheehan, 2008). Contemporarily, it is used especially for treating addictions, such as alcoholism (Hodgins et al., 2009).

Alonso-Prieto et al. (2019) point out the modern use of the SDS as a subjective reflection on the quality of life of patients. They focus on the influence of mental disorders, specifically on serious depressive disorders that are associated with trauma- tic damage of the spinal cord or physical disorders. In clinical practice, we can see the difference between the subjectively and objectively assessed quality of life. The results show that the application of the SDS tool in modern nursing is not radical progress but it can help nursing staff to detect problems they can focus on or advise patients with a large psychological disharmony to consult a psychologist.

Apart from research purposes, the SDS can be used in the treatment of modern addictions, such as gambling. Hodgins (2013), who was focused on the implementation of the SDS in clinical practice regarding the treatment of addictions, monitored the assessments of patients and applied pro-social, assertive and lightly manipulative communication elements in the assessment of risk areas. His pilot study included 21 patients and the main research included 169 patients. A 6- and 12-month rescreening followed. The results show how a person sees their own quality of life in individual areas and how they are affected by potential psychological deficits. He recommends the implementation in clinical practice regarding the treatment of addictions and other illnesses where patients can assess their own health condition.

\section{Conclusions}

There are many tools specifically focused on the assessment of impairments. If we implemented a tool in the Czech clinical practice, we would have to specify the areas of use, who it is for, who would work with it, what we want to find out, how often it will be used, etc. All these aspects can be crucial in the selection. According to the available sources, the most suitable tool for research is the Model Disability Survey, which gives the complex view of a patient's impairment in all areas of social interaction. For the implementation in the Czech practice, a suitable tool could be the Model Disability Survey - Brief version. However, publications proving its validity, reliability, effectiveness and practicality have not been found yet. If we want to proceed according to the EBN/EBP and assess the tools by the above-mentioned criteria, the most suitable tool would seem to be the WHODAS 2.0, which is used in clinical practice in other countries or as the basis for the electronic systems that are created for individual organizations.

\section{Conflict of interests}

The authors have no conflict of interests to declare.

\section{Acknowledgements}

This article is part of the GAJU 058/2018/S research project, which is financially supported by GAJU and carried out at the Faculty of Health and Social Sciences of the University of South Bohemia in České Budějovice. 


\section{Tělesné znevýhodnění v ošetřovatelské praxi - využití vybraných nástrojů $\mathbf{k}$ monitoraci potřeb pacientů s tělesným znevýhodněním}

\section{Souhrn}

Úvod: Tělesné znevýhodnění jakožto multioborový pojem je oproti jiným znevýhodněním (mentální, sociální apod.) považováno za méně problematické. V kontextu ošetřovatelství lze poukázat na mnoho dalších proměnných (inkontinence, vyšší riziko dekubitů, spasticita apod.), jež finálně tvoří obecný pojem známý jako tělesné znevýhodnění.

Cíl: Cílem práce je zmapovat vybrané hodnoticí a měřicí nástroje, které lze aplikovat pro hodnocení potřeb pacientů s tělesným znevýhodněním.

Metodika: Přehledová studie byla realizována s cílem zmapovat vybrané hodnoticí nástroje pro hodnocení potřeb pacientů s tělesným znevýhodněním. Data byla extrahována z odborných databází Scopus, Web of Science, Wiley Online Library, Science Direct, Ebsco a Pubmed za období 2015-2019. Po kriteriálním třídění bylo identifikováno celkem 12 relevantních zdrojů.

Výsledky: V odborných databázích bylo nalezeno celkem 5 možných nástrojů, které jsou relevantní k hodnocení potřeb pacientů s tělesným znevýhodněním. Konkrétně se jednalo o nástroje WHODAS 2.0, MDS, MDS-BV, SDS a ICF.

Závěr: Všechny identifikované nástroje jsou využitelné pro hodnocení pacientů s tělesným znevýhodněním a jsou vhodné pro implementaci do klinické praxe. Bylo by potřeba realizovat výzkum v české klinické praxi, aby byly zjištěny efektivita, praktičnost, validita, reliabilita, specificita a senzitivita vybraných nástrojů.

Klíčová slova: Model Disability Sheehan Disability Scale; Model Disability Survey - Brief version; ošetřovatelství; průzkum; tělesné znevýhodnění; The International Classification of Functioning, Disability and Health; WHODAS 2.0

\section{References}

1. Almazán-Isla J, Comín-Comín M, Damián J, Alcalde-Cabero E, Ruiz C, Franco E, et al. (2014). Analysis of disability using WHODAS 2.0 among the middle-aged and elderly in Cinco Villas, Spain. Disabil Health J7(1): 78-87. DOI: 10.1016/j. dhjo.2013.08.004.

2. Alonso-Prieto E, Rubino C, Lucey C, Evans VC, Tam EM, Woo C, et al. (2019). Relationship between work functioning and selfreported cognitive complaints in patients with major depressive disorder treated with desvenlafaxine. Psychiatry Res 272: 144-148. DOI: 10.1016/j.psychres.2018.12.062.

3. Arbuckle, R, Frye MA, Brecher M, Paulsson B, Rajagopalan K, Palmer S, et al. (2009). The psychometric validation of the Sheehan Disability Scale (SDS) in patients with bipolar disorder. Psychiatry Rese 165(1-2): 163-174. DOI: 10.1016/j. psychres.2007.11.018/.

4. Bond S, Bond J (1982). A Delphi survey of clinical nursing research priorities. J Adv Nurs 7(6): 565-575. DOI: 10.1111/ j.1365-2648.1982.tb00277.x.

5. Bradley SEK, Schwandt HM, Khan S (2009). Levels, Trends, and Reasons for Contraceptive Discontinuation. DHSAnalytical Studies No. 20. Calverton, Maryland, USA: ICF Macro.

6. Carlozzi NE, Kratz AL, Downing NR, Goodnight S, Miner JA, Migliore N, et al. (2015). Validity of the 12-item World Health Organization Disability Assessment Schedule 2.0 (WHODAS 2.0) in individuals with Huntington disease (HD). Qual Life Res 24(8): 1963-1971. DOI: 10.1007/s11136-015-0930-x.

7. Castaneda L, Bergmann A, Bahia L (2014). The International Classification of Functioning, Disability and Health: a systematic review of observational studies. Rev Bras Epidemiol 17(2): 437-451. DOI: 10.1590/1809-4503201400020012ENG.

8. Cieza A, Stucki G (2005). Content comparison of health-related quality of life (HRQOL) instruments based on the international classification of Functioning, Disability and Health (ICF). Qual Life Res14(5): 1225-1237. DOI: 10.1007/s11136-004-4773-0.

9. Č́rtková L, Vitoušová P, et al. (2007). Pomoc obětem (a svědkům) trestných činů: příručka pro pomáhající profese. Praha: Grada.

10. Chiu TY, Yen CF, Chou CH, Lin JD, Hwang AW, Liao HF, Chi WC (2014). Development of traditional Chinese version of World Health Organization Disability Assessment Schedule 2.0 36 - item (WHODAS 2.0) in Taiwan: Validity and reliability analyses. Res Dev Disabil35(11): 2812-2820. DOI: 10.1016/j. ridd.2014.07.009.
11. Coles T, Coon Ch, DeMuro C, McLeod L, Gnanasakthy A (2014). Psychometric evaluation of the Sheehan Disability Scale in adult patients with attention-deficit/hyperactivity disorder. Neuropsychiatr Dis Treat 10: 887-895. DOI: 10.2147/NDT. S55220.

12. Colicchia C, Strozzi F (2012). Supply chain risk management: a new methodology for a systematic literature review. Supply Chain Management 17(4): 403-418. DOI: $10.1108 / 13598541211246558$.

13. Collins JA, Fauser BC (2005). Balancing the strengths of systematic and narrative reviews. Hum Reprod Update11(2): 103-104. DOI: 10.1093/humupd/dmh058.

14. Ehrmann C, Prodinger B, Gmünder HP, Hug K, Bickenbach JE, Stucki G (2018) Describing functioning in people living with spinal cord injury in Switzerland - a graphical modelling approach. Arch Phys Med Rehabil 99(10): 1965-1981. DOI: 10.1016/j.apmr.2018.04.015.

15. Gold MD (2014). DSM-5 and the Assessment of Functioning: The World Health Organization Disability Assessment Schedule 2.0 (WHODAS 2.0). J Am Acad Psychiatry Law 42(2): 173-181.

16. Green BN, Johnson CD, Adams A (2006). Writing narrative literature reviews for peer-reviewed journals: secrets of the trade. J Chiropr Med5(3): 101-117. DOI: 10.1016/S08993467(07)60142-6.

17. Gülpinar O, Güçlü AG (2014). How to write a review article? Turk J Urol 39(1): 44-48. DOI: 10.5152/tud.2013.054.

18. Hanková M, Vávrová S (2016). Partnerské vztahy: očima mladých dospělých s vrozeným tělesným postižením. Praha: Grada.

19. Henderson V (1978). The concept of nursing. J Adv Nurs3(2): 113-130. DOI: 10.1111/j.1365-2648.1978.tb00837.x.

20. Hodgins DC (2013). Reliability and validity of the Sheehan disability scale modified for pathological gambling. BMC Psychiatry13: 177. DOI: 10.1186/1471-244X-13-177.

21. Hodgins DC, Williams R, Munro G. (2009). Work stress, workplace norms and alcohol problems among employed workers. Subst Use Misuse 44(14): 2062-2069. DOI: $10.3109 / 10826080902855173$

22. IHIS CR (2018). WHO Disability Assessment Schedule 2.0 (WHODAS 2.0). [online] [cit. 2019-03-19]. Available from: https://www.uzis.cz/katalog/klasifikace/WHODAS

23. Kalnická V, Votinský J (2008). Výsledky šetření o zdravotně postižených osobách v České republice za rok 2007. Praha: ČSÚ.

24. Kočová H, et al. (2017). Spinální svalová atrofie v souvislostech. Praha: Grada. 
25. Konecky B, Meyer EC, Marx BP, Kimbrel NA, Morissette SB (2014). Using the WHODAS 2.0 to assess functional disability associated with DSM-5 mental disorders. Am J Psychiatry171(8): 818-820. DOI: 10.1176/appi. ajp.2014.14050587.

26. Kučírek J (2017). Aplikovaná psychologie: vybraná témata: teleworking, leadership, sociálně psychologický výcvik. Praha: Grada.

27. Leon AC, Olfson M, Potera L, Farber L, Sheehan DV (1997). Assessing Psychiatric Impairment in Primary Care with the Sheehan Disability Scale. Int J Psychiatry Med27(2): 93-105. DOI: 10.2190/T8EM-C8YH-373N-1UWD.

28. Leonardi M, Bickenbach J, Ustun TB, Kostanjsek N, Chatterji S, MHADIE Consortium (2006). The definition of disability: what is in a name? Lancet368(9543): 1219-1221. DOI: 10.1016/ S0140-6736(06)69498-1.

29. Li K, Yan T, You L, Xie S, Li Y, Tang J, et al. (2016). The inter-rater reliability of the International Classification of Functioning, Disability and Health set for spinal cord injury nursing. Int J Rehabil Res39(3): 240-248. DOI: 10.1097/ MRR.0000000000000176.

30. Lisowska B (2017). How to measure disability: survey usability versus usefulness. Development initiatives [online] [cit. 2019-02-15]. Available from: http://devinit.org/post/measuredisability-survey-usability-versus-usefulness/

31. Loeb M (2016). Development of disability measures for surveys: the Washington group extended set on functioning. International Measurement of Disability 97-122. DOI: 10.1007/978-3-319-28498-9_7.

32. Lu SJ, Liou TH, Yen CF, Chang FH, Chen YL, Escorpizo R et al. (2018). Determinants of Employment Outcome for the People with Schizophrenia Using the WHODAS 2.0. J Occup Rehabil 29(2): 1-9. DOI: 10.1007/s10926-018-9794-6.

33. Lutz BJ, Bowers BJ (2003). Understanding How Disability is Defined and Conceptualized in the Literature. Rehabil Nurs28(3): 74-78. DOI: 10.1002/j.2048-7940.2003.tb02037.x.

34. Madans JH, Loeb ME, Altman BM (2011). Measuring disability and monitoring the UN Convention on the Rights of Persons with Disabilities: the work of the Washington Group on Disability Statistics. BMC Public Health11(Suppl. 4): S4. DOI: 10.1186/1471-2458-11-S4-S4

35. Nagaratnam K, Nagaratnam N (2019). Long-term care, nursing homes and support services. In: Nagaratnam K, Nagaratnam N, Cheuk, G (Eds). Advanced age geriatric care: A comprehensive guide. Cham: Springer International Publishing, pp. 39-43. DOI: 10.1007/978-3-319-96998-5_6.

36. Newbert SL (2007). Empirical research on the resource-based view of the firm: an assessment and suggestions for future research. Strategic Manage J28(2): 121-146. DOI: 10.1002/ smj.573.

37. Opatřilová D, Zámečníková D (2007). Somatopedie: texty k distančnímu vzdělávání. Brno: Paido.

38. Palmer M, Harley D (2012). Models and measurement in disability: an international review. Health Policy Plan27(5): 357-364. DOI: 10.1093/heapol/czr047.

39. Sabariego C, Oberhauser C, Posarac A, Bickenbach J, Kostanjsek N, Chatterji S, et al. (2015). Measuring disability: Comparing the impact of two data collection approaches on disability rates. Int J Environ Res Public Health12(9): 1032910351. DOI: 10.3390/ijerph120910329.
40. Sanches-Ferreira M, Silveira-Maia M, Alves S, Simeonsson RJ (2018). Conditions for Implementing the ICF-CY in Education The Experience in Portugal. Frontiers in Education3(20). DOI: 10.3389/feduc.2018.00020.

41. Sheehan D (1986). The anxiety disease: new hope for the millions who suffer from anxiety. Nex York: Bantam.

42. Sheehan DV, Harnett-Sheehan K, Spann ME, Thompson HF, Prakash A (2011). Assessing remission in major depressive disorder and generalized anxiety disorder clinical trials with the discan metric of the Sheehan disability scale. Int Clin Psychopharmacol26(2): 75-83. DOI: 10.1097/ YIC.0b013e328341bb5f.

43. Sheehan KH, Sheehan DV (2008). Assessing treatment effects in clinical trials with the discan metric of the Sheehan Disability Scale. Int Clin Psychopharmacol 23(2): 70-83. DOI: 10.1097/ YIC.0b013e3282f2b4d6.

44. Silva C, Coleta I, Silva AG, Amaro A, Alvarelhão J, Queirós A, Rocha N (2013). Adaptation and validation of WHODAS 2.0 in patients with musculoskeletal pain. Revista de Saúde Pública 47(4): 752-758. DOI: 10.1590/S0034-8910.2013047004374.

45. Silveira C, Souza RT, Costa ML, Parpinelli MA, Pacagnella RC, Ferreira EC, et al. (2018). Validation of the WHO Disability Assessment Schedule (WHODAS 2.0) 12-item tool against the 36 -item version for measuring functioning and disability associated with pregnancy and history of severe maternal morbidity. Int J Gynecol Obstet 141(Suppl. 1): 39-47. DOI: 10.1002/ijgo.12465.

46. Simeonsson RJ, Leonardi M, Lillar D, Bjorck-Akesson E, Hollenweger J, Martinuzzi A (2009). Applying the International Classification of Functioning, Disability and Health (ICF) to measure childhood disability. Disabil Rehabil 25(11-12): 602-610. DOI: 10.1080/0963828031000137117.

47. Tatli HU, Köseoglu BF, Özcan DS, Akselim SK, Doğan A (2019). Validation and application of the international classification of functioning core set for spinal cord injury in the Turkish patients. Turk J Phys Med Rehab 65(10): 1-15. DOI: 10.5606/ tftrd.2019.3045.

48. Tranfield D, Denyer D Smart P (2003). Towards a methodology for developing evidence-informed management knowledge by means of systematic review. Br J Manag 14(3): 207-222. DOI: 10.1111/1467-8551.00375.

49. Üstün TB, Chatterji S, Kostanjsek N, Rehm J, Kennedy C, Epping-Jordan J, et al. (2010). Developing the World Health Organization disability assessment schedule 2.0. Bull World Health Organ 88(11): 815-823. DOI: 10.2471/BLT.09.067231.

50. WHO (2001). International Classification of Functioning, Disability and Health (ICF). [online] [cit. 2019-03-19]. Available from: https://www.who.int/classifications/icf/en/

51. WHO (2013). WHO [online]. Geneva: WHO. [online] [cit. 201903-19]. Available from: https://www.who.int/classifications/icf/ whodasii/en/

52. WHO (2017). Model Disability Survey. [online] [cit. 2019-0319]. Available from: https://www.who.int/disabilities/data/ mds/en/

53. WHO (2019). Model disability survey. [online] [cit. 2019-0319]. Available from: https://www.who.int/disabilities/data/ mds/en/ 